\title{
Correction to: Interdisciplinary Collaboration Training: An Example of a Preservice Training Series
}

Nicole Boivin ${ }^{1}$ • Jennifer Ruane ${ }^{2} \cdot$ Shawn P. Quigley ${ }^{2} \cdot$ Jill Harper $^{1} \cdot$ Mary Jane Weiss $^{2}$

Published online: 3 May 2021

(C) Association for Behavior Analysis International 2021

Correction to: Behavior Analysis in Practice. https://doi.org/10.1007/s40617-021-00561-z

This article was updated to correct the affiliation of Mary Jane Weiss.

Publisher's Note Springer Nature remains neutral with regard to jurisdictional claims in published maps and institutional affiliations.

The online version of the original article can be found at https://doi.org/ $10.1007 / \mathrm{s} 40617-021-00561-\mathrm{z}$

Nicole Boivin

nboivin@melmarkne.org

1 Melmark New England, 461 River Rd, Andover, MA 01810, USA

2 Melmark Pennsylvania, Berwyn, PA, USA 